\title{
DISCOURSES ON SOCIAL BARRIERS IN RUSSIAN (COUNTER) INNOVATION SYSTEM: REALITY OR NARRATIVE?
}

Vyacheslav V. VOLCHIK - Doctor of Economics, Head of Economic Theory Department, Southern Federal University, Rostov-on-Don, Russia (volchik@sfedu.ru).

\begin{abstract}
The aim of the study is to identify and critically analyze the explanations of the gap between the good level of Russian science and relatively weak development of domestic innovative production. The study of a series of expert interviews identified four key problems: low business demand for innovation; failures in public management of innovation studies; declining reproduction of scientific research personnel; and institutional barriers to patenting "real" innovation. Discourse analysis leads to the conclusion that the main brake for the Russian innovation system is the poor quality of public administration. Based on the approach of narrative economics, doubts are expressed about the unconditional objectivity of such a conclusion: experts can reproduce "viral" narratives (stereotypes), which distortedly reflect reality. A critical approach to the studied interviews shows that some "accusations" against government regulation of innovation studies are unreliable or inaccurate. Therefore, popular expert judgments about poor government regulation should be viewed as a superficial level of explanation of the failures of innovation studies in post-Soviet Russia.

Keywords: sociology and economics of innovation studies $\bullet$ national innovation system • social factors of innovation studies $\bullet$ discourse analysis of innovation • narrative economics • government regulation
\end{abstract}

DOI: $10.31857 /$ S013216250017614-8

This article is a translation of: Дискурсы о социальных барьерах российской (контр) инновационной системы: реальность или нарратив? // Sotsiologicheskie Issledovaniia. 2021. No 10: 61-71. DOI: 10.31857/S013216250016089-0

The original work was supported by the grant of Russian Science Foundation No. 21-18-00562, https://rscf.ru/en/project/21-18-00562/

National innovation system as an object of socio-economic analysis. Domestic and foreign researchers of social aspects of development of technological innovations note a paradox: Russia has many outstanding scientists and inventors, but few innovative products of its own production (see, for example: [Graham, 2014; Auzan et al., 2019]). L. Graham, a wellknown American researcher of the social history of Russian science, writes that for centuries there have been powerful social obstacles to technological success in Russia: "Some of them, such as the lack of effective legislation on innovation, are obvious and easy to explain. Others, such as the factor of the prevailing social attitude to innovators, are difficult to formulate unequivocally. But they play a very important role" [Graham, 2014: 146]. The study of "society's existing attitudes toward innovators" requires an interdisciplinary approach that is connected not only with sociological analysis, which focuses on "people who play games", but also with institutional economic analysis, which considers "the games people play".

The main idea of modern institutional economic theories, coming from T. Veblen and R. Coase, is to approach economic life as a system of formal and informal institutions ("rules of the game", formal rules and informal standards of behavior [North, 1989: 1321]), consciously chosen and/or spontaneously formed. Institutional factors are considered in this case in a wide range - from cultural practices to the instrumental aspects of the (im)perfection of legal regulation. Evolutionary economic theory, which is concentrating on the institutions of generation 
and dissemination of innovations, is connected with institutional economic theory. In the framework of modern evolutionary economics, the concept of national innovation system has been formed - a country-specific "set of separate institutions, which jointly and individually contribute to the development and distribution of new technologies and provide the basis for the formation and implementation of the public policy influencing the innovation process. In essence, it is a system of interconnected institutions for the creation, holding and transfer of knowledge, skills and artifacts that determine new technologies" [Metcalfe, 1995: 38]. Features of innovative systems depend on the embeddedness of effective social technologies (institutional environment), which can help / hinder the use of the potential of technological innovation [Lundvall, 2016: 80]. This approach to innovation studies on the part of economists is similar to the approaches of sociologists studying innovations, who also seek a comprehensive analysis of aspects of interactions between actors of the innovation system (see, e.g.: [Latova, Latov, 2014; Klyucharev et al., 2016]).

The object of our analysis will be the Russian innovation system, and the specific subject will be social interactions of its actors. This article will demonstrate the creativity of combining the approaches of sociology and economics of innovation studies to identify the social factors that explain the paradox of the Russian innovation system, and to critically analyze the usual methods of identifying these factors.

Methodology of discourse analysis of "rules of the game" of the actors of the Russian innovation system. In order to understand the essence of national innovation processes, social scientists, first of all, organize surveys of actors of these processes and theoretically generalize their opinions.

Four groups of the main actors of national innovation system can be identified:

researchers and administrators representing the field of innovation generation,- producers of innovations;

entrepreneurs and business managers (small innovative businesses, corporate innovators) consumers of innovations;

the government acting through representatives of regulatory bodies and heads of innovative public enterprises - administrators-regulators;

the population of the country, which consumes innovative products and feed the ranks of creators of innovations.

Each of these social groups has its formal and informal "rules of the game" affecting the generation and implementation of new technologies. In order to understand the obstacles to innovations, representatives of the first group are mostly interviewed, since they are more deeply involved in innovative processes being the experts in them.

When analyzing the reasons for low technological innovativeness in Russia, sociological studies have identified certain groups of factors. Thus, in a study [Savinkov et al., 2021: 20], based on a survey of experts, three main factors hindering the transition of domestic enterprises to active use of innovation were formulated: lack of qualified creative thinking specialists; lack of government support; insufficient resources for research, design and development activities and commercialization of ideas. This typology is based on the idea of the paramount importance for the generation of innovations of three types of resources - labor, management and capital. However, this scheme does not seem to fully take into account the real diversity of interrelations between the actors of innovation system. In order to theoretically systematize the collected opinions, it is proposed to proceed from the standard for economic science logical model of interaction of three actors of market economy - households (population), companies (business) and the government. As can be seen from the proposed scheme (Fig.), on the basis of preliminary thematic processing of interviews four key problems inhibiting domestic innovation system were identified: demand for innovation; public management of innovation studies; reproduction of personnel (including research schools and implicit knowledge); commercialization of innovation (generation of patents, etc.). 


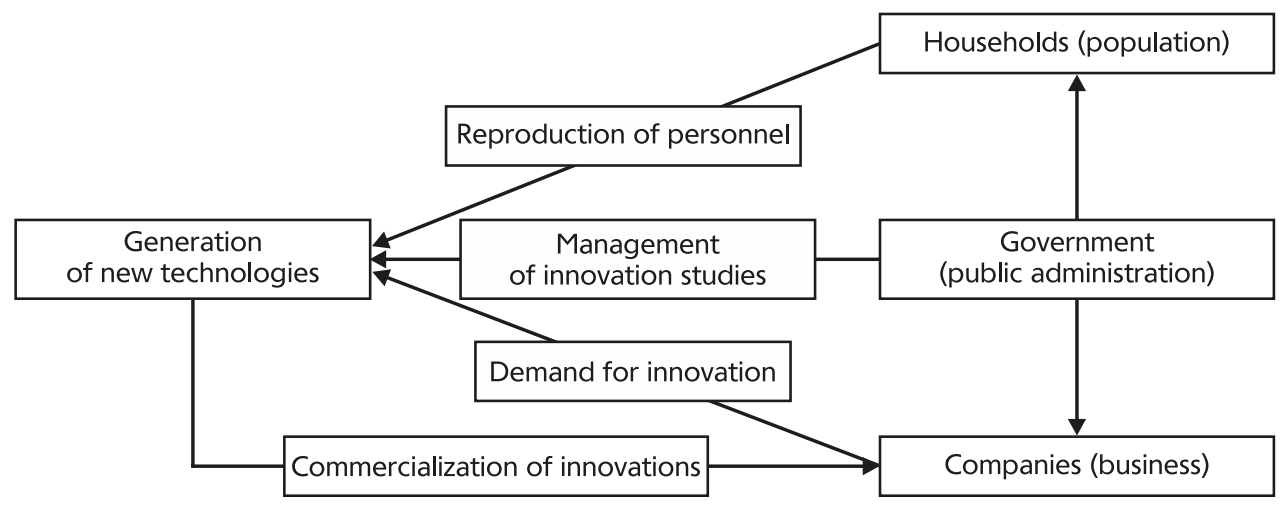

Figure Actors and factors of national innovation system

Identification and study of the problems of the Russian innovation system is currently based primarily on interviewing and discourse analysis of interviews of its actors (see: [Bychkova et al., 2019; "Continuous Education..." Report, 2018: 137-216; Klyucharev, Chursina, 2021], etc.). This article will first characterize each of the four institutional problems shown in the figure based on discourse analysis of expert interviews, and then provide a critical analysis of this approach.

The original sources of qualitative data were 9 in-depth interviews conducted in 2014-2017 with regional representatives of the academic and industrial fields related to innovation activities. Another source of expert judgments about innovations were media publications - 21 interviews with key Russian scientists at the federal level, which were posted in 2018-2020 on the portal of "Kommersant" Publishing House under the "Physically it is possible" heading of "Ogonyok" and "Kommersant Nauka" magazines.

Demand for Innovation. The Soviet attempt to replace market competition with centralized management of innovation has shown that market mechanisms have no alternatives in generating the demand for innovation so far. At the same time, market mechanisms in the innovation sector need the institutional infrastructure provided by the government that minimizes transaction costs of interconnection of business and science. In modern Russian conditions, this is supplemented by the actual monopoly of the government in a number of key industries and, consequently, monopoly on innovations in them. In almost all the interviews of the actors in the sector of innovations generation, the opinion was expressed that Russian entrepreneurs have no interest in new developments. In some interviews this was articulated directly: "The problem that scientists face... is that businesses have no need for innovation in the first place" (university professor, expert in youth entrepreneurship, Nizhny Novgorod).

It is necessary to pay attention to significant differences in the demand for innovation studies in different industries: "The economy today works in such a way that the tone of innovative developments is set by the oil production and military-industrial complexes. Just like in the Soviet times, physics and chemistry are our priority now, biomedicine is also "scores a big win" lately. Money is being spent on health care [also by the government]... As for the rest, only the market [can provide financing]..." (Director General of the University of Small Innovative Enterprise, Nizhny Novgorod). The problem is that the relevance of industries can change by leaps, and the temporary lag behind of the industry risks becoming irreversible, as the lagging industry loses the ability to implement advanced innovations. Symptomatic in this regard is the failure with the introduction of nanotechnologies in Russia, which in the late 2000s were officially called "the top priority direction of development of science and technology". A.G. Nasibulin, a leading Russian expert on nanotechnologies, directly pointed out that "one 
of the main problems of introduction of nanotechnologies in Russia is that there is nowhere to introduce them» ${ }^{1}$.

The gap between science and production is largely due to underdevelopment in Russia of special institutions facilitating regular relations between the academic field and business. This fundamental shortcoming can be noticed mainly by those who know the foreign "rules of the game" well: "I remember working in Great Britain for several months as a visiting professor. Every week people from the so-called "smart institute" came to me, this institute was looking for some new solutions and technologies, and they asked me what I had to solve this or that problem. We in Russia do not have it in the first place" (member of the Russian Academy of Sciences, Rostov-on-Don). The absence of intermediary organizations that help scientists learn about business demand for specific innovations forces scientists to simultaneously be researchers, administrators and entrepreneurs, ignoring the principle of division of labor.

In order to explain strange (by the standards of developed countries) indifference of Russian business to innovations, we can refer to the concepts of the evolutionary economic theory. The economic analysis of innovation accepts the premise that innovator companies are encouraged to adopt new technologies because it allows them to obtain high additional profits [Nelson, 2018: 20]. But in post-Soviet Russia, due to the specifics of the national institutional environment, innovator companies do not receive sufficient benefits from innovative monopoly. The benefits of obtaining an administrative monopoly are more significant due to the barriers associated with government regulation. Therefore, for domestic entrepreneurs, investment in political rent-seeking is more profitable than investment in innovations.

Public management of innovation studies. The role of the government in modern innovation studies remains an unresolved problem in Russia and abroad. All recognize that the government's choice of priority research topics/direction is of great importance for the coordination of scientific research organizations. The question is how well politicians and government officials manage to choose these priorities so that rent-seeking considerations would not prevail over reasonable social considerations. This problem is more important for Russia than for highly developed countries, because it is government organizations that assume the lion's share of funding for domestic scientific projects and technological developments (see, for example: [Dezhina, Medovnikov, Rozmirovich, 2019]).

"Disconnection" of Russian business from management of technological innovation studies created irreconcilable conflict of interests between academic science and state bureaucracy, claiming leadership in the choice of priorities of financing of innovation studies. Since in postSoviet society administrative resources are more important than scientific authority, a system of public management of innovation studies where "the government is stronger than (scientific) community" was formed. The famous Russian psychologist, D.V. Ushakov, member of the Russian Academy of Sciences, characterized it this way: "Enormous money in the country is spent on applied sectoral science through public agencies. In order to make these expenditures more meaningful in terms of the strategy of scientific and technological development of Russia, priority councils were created to form major full-cycle programs (from fundamental developments to the actual product), which are justified from the perspective of fundamental science and at the same time are needed from the perspective of authorities. The idea is great, but it does not work well because the authorities are not at all interested in spending resources with the knowledge of big science" ${ }^{\prime 2}$.

Russian "big science" has tried to strike back at the bureaucrats and create a system of objective scientific expertise of the situations in the priority areas of scientific innovation studies chosen by the bureaucrats. This refers to the Corps of Experts in Natural Sciences, which

1 "I wanted to create milk from grass, removing the cow from the process": Albert Nasibulin, Physicist, on advanced technologies // Ogonyok. 2019. 21 January. No. 2. P. 32. URL: https://www.kommersant.ru/ doc/3853898 (accessed on: 18.08.2021).

2 There will be a revolution in scientific management of society // Kommersant Nauka. 2020. 30 September. No. 24. P. 37. URL: https://www.kommersant.ru/ doc/4501983 (accessed on: 18.08.2021). 
was formed by self-organization in the late 2000s. M. Feigelman, Russian physicist, one of the initiators of this institute, describes it as follows:

"The Corps of Experts is a constantly replenished list of experts in natural science subjects, selected on the basis of the recommendations of scientists. Today it is a working system to sort out who is worth what in science. It has been created, but you can't say that anyone actually uses $i^{\prime \prime}{ }^{3}$. Indeed, in the late 2010s officials simply stopped seeking expertise from Corps members: according to the organization's server, its last expertise (an audit of Skoltech units) was conducted in $2017^{4}$.

We must make a reservation that the contradictions between bureaucratic control and academic expertise are global in scope. Abroad, the decline in trust with regard to professional experts is interpreted [Nichols, 2019] in the context of the conflict between meritocratic elites and "commoners". In Russia, however, there seems to be a different conflict - between the scientific community, which is trying to institutionalize itself as an element of civil society, and the state bureaucracy, which is trying to avoid civil control.

Reproduction of personnel. Reproduction of scientific-research personnel is organically connected with the priority value for innovation studies of human capital - knowledge, abilities and motivation embodied in a person. In modern Russia, the problem of reproduction of such personnel is a logical continuation of the failures of bureaucratic management of science: a managerial policy has long been implemented in the academic field, which resulted in a strong (by 23\% in 2000-2019 alone) reduction of "personnel engaged in research and development" [Volchik et al., 2019].

Since human and financial capitals in science are complementary rather than interchangeable resources, investments in scientific equipment cannot produce effects if there are no people willing and able to work efficiently on it. F.I. Ataullakhanov, a leading Russian biophysicist, directly points out that "today the main problem in Russia is not the lack of equipment. Decent money is being invested in equipment, but absolutely nothing works out. Why? Because there are no specialists... Today a Russian scientist receives so little that the attractiveness of this field is equal to zero". Of course, a good scientist is a person with a dominant "post-monetary" motivation. However, such scientists are critically dependent on the availability of scientific schools. "Who goes into physics or biophysics in Russia today? Fanatics, who are born from time to time in any country and at any time," says F.I. Ataullakhanov on the subject. "But today there is nowhere in Russia for such a person to study, and he is looking for ways to go to countries where science is at a higher level... You see, in addition to buying equipment you need pave the way" ${ }^{5}$.

Indeed, in science and applied research the productivity of scientists very much depends on the environment where they work and interact. M. Polanyi noted the high importance of implicit (unformalized) knowledge for both research activities and technology as early as the 1950s [Polanyi, 2012]. Modern scientists know well from personal experience that in the process of scientific activity not only codified, but also personal knowledge is created, the absence of which makes the progress of a scientist impossible. D.V. Ushakov expressed it this way: "Personal knowledge plays a huge role in science. Nowadays any information can be obtained from articles, books, the Internet - the flow of information is enormous. But much more important is what cannot be formulated explicitly... You cannot get this personal knowledge from books, and you either form it yourself or have personal contacts with other scientists. So, the opportunity

3 "There is practically no real high tech in Russia." Mikhail Feigelman, Deputy Director of the Institute of Theoretical Physics of the Russian Academy of Sciences, on the society lagging behind the science // Ogonyok. 2019. 17 June. No. 23. P. 30. URL: https://www.kommersant.ru/doc/3998209 (accessed on: 18.08.2021).

${ }^{4}$ Corps of Experts on Natural Sciences. URL: http://www.expertcorps.ru/science/about (accessed on: 18.08.2021).

5 "If humanity wants to survive, it must be dying": Fazoyil Ataullakhanov, scientist - about the advanced and most unusual field of physics // Ogonyok. 2020. 13 July. No. 27. P. 28. URL: https://www. kommersant. ru/doc/4406396 (accessed on: 18.08.2021). 
to communicate with a major scientist in your chosen field is a big bonus" ${ }^{6}$. Consequently, the reproduction of scientific research personnel necessarily implies the reproduction of scientific schools clustered around major scientists.

Personnel reproduction issues in the Russian context are also often solved in the spirit of managerialism policy by adopting targets and introducing programs to support young scientists. But they must see that their temporary support in the rank of a young scientist in the future with a high probability will turn into a stable and financially competitive trajectory of a mature researcher, and this does not always happen. The practice of supporting young scientists to the detriment of supporting scientific schools is therefore criticized. It is not uncommon to see situations when young researchers use independent grants not too effectively, and when they leave young age they leave science or go abroad: "Today you are 35, you are a young scientist and get a grant, and tomorrow you are 36, and you get nothing. And a young person should think about a family, an apartment, but now there are no guarantees for this" (member of the Russian Academy of Sciences, Rostov-on-Don).

Reproduction of innovative personnel implies great attention not only to the researchers themselves, but also to the staff serving them, specializing in the manufacture of special equipment. Important evidence of the strong influence of implicit knowledge on the specifics of Russian high-tech production is noted in an interview about the situation with the development and production of Proton space carrier rockets:

"These rockets were made in Moscow by Khrunichev design bureau (DB). Everything would have been fine if the $D B$ was not in Moscow. Some of our actors decided to optimize the work of the $D B$, that is to move production to Omsk and sell this territory... So, they did... [But try] make these workers, workers of the highest qualifications, to move from Moscow to Omsk to do something there. They just all retired and that's it. In such a unique rocket, the documentation is far from reflecting everything... There is know-how at the level of "uncle Joe Blow" - how to "tinker, tap on" something. And now it was decided to take these rockets out of production, because everything that was done in this production facility in Omsk turned out to be, to say the very least, of low quality" (Chief Researcher, Rostov-on-Don).

It is important to note that almost all problems of reproduction of personnel in the field of innovation studies - headcount reduction, weak attention to scientific schools, etc.- as it is evident from the interview, are connected in one way or another with the drawbacks of public management of science.

Commercialization of innovations. Intellectual property for a useful invention protected by a patent is a key element of modern national innovation systems, forming stable channels of innovation transfer from the source (inventor) to the recipient (company). However, under Russian conditions, the institution of patents does not always fulfill this function.

The collected interviews show that patents are a self-sufficient indicator of the performance of a scientist and scientific organizations for innovators from academia, even if it does not come to their practical implementation. "For university employees, a patent is still not a way to protect intellectual property, but rather an indicator of the scientist's importance... The scientist needs it to fill out grant applications, for ratings, when recertifying or being elected to a new position" (professor, expert in the field of youth entrepreneurship, Nizhny Novgorod). If patents are included in the system of administratively controlled indicators, then inevitably people will "work for the indicator". In this regard, one of the interviewees directly noted that "it is necessary to move away from patenting "just for the check in the box" and for university reporting, because the creation of this kind of patents destroys technology development" (employee of the Center for Commercialization of Technology, Nizhny Novgorod).

${ }^{6}$ There will be a revolution in the scientific management of society: Dmitry Ushakov, member of the Academy of Sciences - about the psychological mechanism of transmission of viral infection // Kommersant Nauka. 2020. 30 September. No. 24. P. 37. URL: https://www.kommersant.ru/ doc/4501983 (accessed on: 18.08.2021). 
The functioning of the institution of patents in Russia is also associated with significant administrative barriers and restrictions. Here is a typical story about bureaucratic sabotage, as told by the head of one of the research institutes at the Southern Federal University: "Several large companies in our pharmaceutical industry, which are ... in foreign hands, want to buy our patents. ...To the Ministry of Education's credit, they allowed the sale of patents. But the Ministry of Health said emphatic no. It turns out that in all the years of its existence, the Ministry of Health has never sold a single patent. They haven't sold any, not because there are no offers, but because there are officials sitting there, none of whom ... want to put their signature on it. He'll put his signature there, and tomorrow he'll be accused of allowing intellectual property to be sold. That's why the official does not put his signature" (member of the Russian Academy of Sciences, Rostov-on-Don).

Thus, the existing administrative and managerial "rules of the game" rather hinder the commercialization of scientific developments than help them. After all, in the Russian system, the institution of intellectual property protection is built into the existing institutional structure, where loyalty to the government is more important than innovation.

Conclusions from the discourse analysis and their limitations. The review of the collected materials leads to the conclusion that the poor quality of public management of Russian innovation system is the main obstacle to its development. Virtually all of the analyzed interviews constantly rebuke state bureaucrats and managers who do almost everything "wrong". The government creates such "rules of the game" for business that the demand for innovations is extinguished by the demand for political rent-seeking. It monopolizes the management of innovations, pushing more competent academic circles away from it. It replaces expanded reproduction of scientific research personnel with expanded reproduction of reporting documentation. It discourages the real patent activity of inventors. In a word, it is possible to raise the question of what really exists - the Russian innovation system or the Russian counter-innovation system.

At the same time, there are considerations that cast doubt on the unconditional objectivity of the conclusion that failures of public management of Russian innovation system are the main and almost the only "causers" of its modern "not quite" successful development.

In recent years, a new scientific trend called a narrative economic theory (Narrative Economics) has been gaining popularity in foreign economic science. Narratives are popular images (stereotypes, "stories", memes), under the influence of which people make decisions in everyday life.

Narrative economists are taking another step away from the once familiar image of the decision-maker as a rationalist who knows precisely and constantly compares the benefits and costs of alternative behaviors. Modern economists are getting closer and closer to the model of human behavior familiar to sociologists - the individual's desire to be guided by generally accepted standards in his social environment. This is why Western economists' attention to "narratives" bears a striking resemblance to sociologists' trivial desire to find out, through surveys or interviews, what values/patterns/standards people are really guided by in their everyday lives. When economists say that in order for new narratives to become meaningful for shaping the rules of social behavior, they must go "viral" [Shiller, 2019], from a sociologist's perspective we are talking about the ordinary spread of the popularity of a new cultural practice. Accordingly, the study of narratives for information about practices and rules that economists call for is the banal discourse and content analysis of media texts and interviews that sociologists have been doing for almost a century.

However, the narrative economics has an important aspect that has innovative implications for sociologists as well: economists emphasize that the evaluations and patterns expressed in popular narratives often do not correspond to objective reality. In order to demonstrate the destructive role of narratives, R. Shiller, American economist, gives the following example: over the last half-century there was only one period of fast growth in the Western real estate market, on the eve of the 2007-9 Great Recession, and there were no objective indicators at its core; the unknown factor that triggered the boom, speculation bubble and crisis, was exactly the popular stories about hyper-profitable real estate investments [Shiller, 2019]. "The blame" 
for false narratives can be placed on both the spontaneous "madness of the crowd" and the deliberate manipulation of public consciousness by professional marketers and political technologists. The idea of "virality" of false narratives (stereotypes) emphasized by supporters of Narrative Economics thus reveals fundamental limitations of the methods of discourse and content analysis, which have recently been gaining popularity among domestic social scientists.

If we look at the opinions about the inhibition of Russian innovations by the "bad" government as a popular narrative, a stereotype of public consciousness, then the objectivity of the collected evidence becomes questionable. Moreover, the expert scientists involved in the production of innovations are themselves representatives of a certain social group, whose interests were described by L.A. Artsimovich, Soviet physicist, with the aphorism: "Science is the best way to satisfy personal curiosity at public expense." Of course, research scientists have a civic awareness, but to what extent do they condemn bureaucrats particularly as citizens and not as privilege-seeking meritocrats who take up and replicate "stories" that benefit them?

Among the above interview "stories" there is at least one that is a glaring example of false narratives. This is the story of the "Protons", which were supposedly successfully produced until the bureaucrats wished to take away a piece of valuable Moscow land. In fact, in 2019 Khrunichev design bureau was indeed moved from Moscow to Omsk, and in the same year the "Protons" were taken out of production. However, the decision to abandon their production was made back in 2018 due to a series of previous accidents. With such a presentation, the a priori harmfulness of the bureaucrats managing innovation studies is no longer obvious. Another example of dissonance between the usual narrative and reality is an interesting discussion by M.V. Feigelman, the outstanding physicist, on the peculiarities of the geography of modern Russian science. "Naturally, it is largely concentrated in Moscow and Moscow region...", this expert testifies. "[However,] a number of anomalies are striking, for example, in chemistry. A great proportion of chemical scientists are concentrated in the gigantic Moscow academic institutes. But if you look at where any notable scientific production comes from, it turns out to be the Urals and Siberia." ${ }^{7}$ And the Urals and Siberia is primarily Tyumen, the center of the Russian "oil industry". Since modern applied chemistry is largely petrochemistry, the expert actually notes the attraction of the center of scientific and technological innovation to the center of the corresponding business. This contradicts the popular opinion that Russian business, due to poor public management, does not generate demand for innovations at all.

It should be borne in mind that the thesis, which goes back to T. Hobbes' "Leviathan", about the government imposing only ineffective "rules of the game" on society, is itself a hyper-popular "narrative", and it is not only liberal and left-wing political oppositionists who propagate it in today's Russia. Those who lived through the 1980s and 1990s remember that when a very similar idea "seized the masses" and became an "arm of flesh" 30 years ago, its practical implementation was "not very" successful.

Apparently, in addition to the failures of government regulation under a particular political regime, there are deeper reasons associated with the specifics of the institutional environment of the Russian economy, due to which these failures have become a sad national tradition. Their identification and analysis require a separate study. At a very first approximation, we can only assume that a very important role is played by national traditions of values and culture, which welcome orthodoxy rather than the search for novelty. We are talking about a shift in the analysis of obstacles to innovations from formal institutions created by the state to informal institutions formed by the national mentality. V.L. Tambovtsev, the leading Russian economistinstitutionalist, has already expressed the idea that "in order to formulate recommendations

7 "There is practically no real high tech in Russia." Mikhail Feigelman, Deputy Director of the Institute of Theoretical Physics of the Russian Academy of Sciences, on the society lagging behind the science // Ogonyok. 2019. 17 June. No. 23. P. 30. URL: https://www.kommersant.ru/doc/3998209 (accessed on: 18.08.2021). 
regarding the use of national or regional culture features to influence innovation processes, it is necessary to understand how subjective standards of real and potential actors of these processes are arranged" [Tambovtsev, 2018: 84-85].

In any case, when analyzing the "attitude towards innovators, existing in the society" that L. Graham wrote about, it is in no event possible to dwell on the statement of the claims of innovator scientists to bad public administration. These claims are certainly not without reason, but the analysis needs to be broader and deeper.

\section{REFERENCES}

Auzan A.A., Komissarov A.G., Bakhtigaraeva A.I. (2019) Sociocultural Restrictions on the Commercialization of Innovations in Russia. Ekonomicheskaya politika [Economic Policy]. Vol. 14. No. 4: 76-95. (In Russ.)

Bychkova O.V., Gladarev B.S., Kharkhordin O.V., Tsinman Zh.M. (2019) Fantastic Worlds of Russian Hightech. St. Petersburg: EU v SPb. (In Russ.)

Dezhina I.G., Medovnikov D.S., Rozmirovich S.D. (2019) State Support of Small Innovative Companies by the Fund for Assistance to Innovations. Sotsiologicheskie issledovaniya [Sociological Studies]. No. 11: 110-119. DOI: 10.31857/S0132162500074474. (In Russ.)

Graham L. (2014) Will Russia be Able to Compete? A History of InnovationS in Tsarist, Soviet and Modern Russia. Moscow: Mann, Ivanov i Ferber. (In Russ.)

Kliucharev G.A., Chursina A.V. (2021) Hightech Industries for an Innovative Economy: Expert Opinions. Vestnik Rossijskogo universiteta druzhby narodov. Seriya: Sotsiologiya [RUDN Journal of Sociology]. Vol. 21. No. 1: 68-83. DOI: 10.22363/2313227220212116883. (In Russ.)

Klyucharev G.A., Didenko D.V., Latov Yu.V., Latova N.V., Sheregi F.E. (2016) Education, Science and Business in Creating Intelligent Environments. St. Petersburg: Nestorlstoriya. (In Russ.)

Latov Yu.V., Latova N.V. (2014) The Formation of Technology as a Highest Stage of Development of the Science. Obshchestvennye nauki i sovremennost' [Social Science and Contemporary World]. No. 5: 142-156. (In Russ.)

Lundvall B.Å. (2016) Innovation as an Interactive Process: From User-Producer Interaction to the National Systems of Innovation. In: The Learning Economy and the Economics of Hope. New York: Anthem Press: 61-84.

Metcalfe J.S. (1995) Technology Systems and Technology Policy in an Evolutionary Framework. Cambridge Journal of Economics. Vol. 19. No. 1: 25-46. DOI: 10.1093/oxfordjournals.cje.a035307. Nelson R.R. (2018) Economics from an Evolutionary Perspective. In: Modern Evolutionary Economics: An Overview. Cambridge, UK: Cambridge Univ. Press: 1-34.

Nichols T. (2019) The Death of Expertise: The Campaign against Established Knowledge and Why it Matters. Moscow: Bombora. (In Russ.)

North D.C. (1989) Institutions and Economic Growth: An Historical Introduction. World Development. Vol. 17. No. 9: 1319-1332. DOI: 10.1016/0305750X(89)900752.

Polanyi M. (2012) Personal Knowledge. London: Routledge.

Report "Continuing Education and Knowledge-intensive Industries: Institutions and Practices of Interaction". (2018) Based on the Results of a Scientific Project Carried out with the Support of the Russian Science Foundation (No. 161810420). URL: https:// obrazovanie_i_naukoemkie_proizvodstva_2018_final.pdf (accessed 18.08.2021). (In Russ.)

Savinkov V., Popov M., Klyucharev G. (2021) Innovative Enterprises in Universities: Issues of Integration with the Real Sector of the Economy. Moscow: YURAIT. (In Russ.)

Shiller R.J. (2019) Narrative Economics: How Stories Go Viral and Drive Major Economic Events. Princeton: Princeton Univ. Press.

Tambovtsev V.L. (2018) Innovations and Culture: Importance of the Analysis Methodology. Voprosy Ekonomiki. No. 9: 70-94. DOI: 10.32609/00428736201897094. (In Russ.)

Volchik V.V. (2020) Narratives and Understanding of Economic Institutions. Terra Economicus. Vol. 18. No. 2: 49-69. DOI: 10.18522/2073660620201824969. (In Russ.)

Volchik V.V., Koryttsev M.A., Maslyukova E.V. (2019) Institutions and Ideology of Managerialism in Higher Education and Science. Upravlenets [The Manager]. Vol. 10. No. 6: 15-27. DOI: 10.29141/2218500320191062. (In Russ.) 